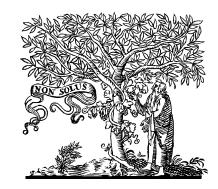

ELSEVIER
GfÖ

GfÖ Ecological Society of Germany, Austria and Switzerland

Basic and Applied Ecology xxx (2015) xxx-xxx

\section{Basic and Applied Ecology}

www.elsevier.com/locate/baae

\title{
Metapopulation processes affecting diversity and distribution of myrmecophiles associated with red wood ants
}

\author{
T. Parmentier ${ }^{\mathrm{a}, \mathrm{b}, *}, \mathrm{~W}$. Dekoninck ${ }^{\mathrm{b}}, \mathrm{T}$. Wenseleers ${ }^{\mathrm{a}}$ \\ ${ }^{a}$ Laboratory of Socioecology and Socioevolution, KU Leuven, Naamsestraat 59, B-3000 Leuven, Belgium \\ ${ }^{\mathrm{b}}$ Royal Belgian Institute of Natural Sciences, Entomology Department, Vautierstraat 29, B-1000 Brussels, Belgium
}

Received 13 October 2014; received in revised form 14 April 2015; accepted 15 April 2015

\begin{abstract}
Red wood ants support a diverse community of myrmecophiles in their nest mounds. Given that nest mounds provide fairly constant and distinct habitat patches for myrmecophiles, metapopulation and metacommunity dynamics can be expected to play an important role in structuring myrmecophile communities. Here, we investigate how site, site size (i.e. number of mounds per site), mound isolation, mound size, moisture, $\mathrm{pH}$ and red wood ant host (Formica rufa and Formica polyctena) affect the (meta)community composition and species richness. We demonstrate that community composition is structured by site and within-site isolation. In addition, species richness per unit volume is negatively correlated with increasing nest mound isolation. Mound size and site size at a higher spatial scale had no effect on community composition or diversity. The latter suggests that few mounds are required to support the minimum viable metapopulation size. We did not find support that the environmental variables mound moisture and $\mathrm{pH}$ affect the myrmecophile community or its species richness. Finally, the communities of the two closely related wood ant species $F$. rufa and F. polyctena were very similar. Overall, our results demonstrate, in accordance with metapopulation theory, that isolated mounds support fewer myrmecophile species. Diverse myrmecophile metacommunities also occur in small red wood ant sites, with well connected nest mounds. We discuss the powerful potential of ant nests, and particularly red wood ant mounds, for metapopulation and metacommunity research.
\end{abstract}

\section{Zusammenfassung}

Rote Waldameisen beherbergen eine diverse Gemeinschaft von Ameisengästen in ihren Nesthaufen. Da die Nesthaufen recht konstante und eigenständige Habitate bilden, kann erwartet werden, dass Metapopulations- und Metagemeinschaftsdynamik eine wichtige Rolle bei der Bildung von Myrmekophilengemeinschaften spielen. Wir untersuchten wie der Standort, die Anzahl der Nester je Standort, die Isolation der Nester, die Nestgröße, Feuchtigkeit, pH und die Art der Wirtsameise (Formica rufa oder Formica polytena) Zusammensetzung und Artenreichtum der (Meta-)Gemeinschaft beeinflussen. Wir zeigen, dass die Zusammensetzung der Gemeinschaft durch den Standort und die Isolation der Nester innerhalb des Standortes strukturiert wird. Der Artenreichtum pro Volumeneinheit ist negativ mit zunehmender Isolation der Nesthaufen korreliert. Die Größe der Nesthaufen und die Zahl der Nester pro Standort hatten keinen Effekt auf Zusammensetzung und Diversität der Gemeinschaft. Letzteres legt nahe, dass wenige Nester benötigt werden, um eine minimale überlebensfähige Größe der Metapopulation aufrechtzuerhalten. Wir fanden keinen Anhaltspunkt dafür, dass Feuchtigkeit im Nest und der pH-Wert Zusammensetzung oder

\footnotetext{
${ }^{*}$ Corresponding author at: Laboratory of Socioecology and Socioevolution, KU Leuven, Naamsestraat 59, B-3000 Leuven, Belgium. Tel.: +32016 32 3975; fax: +32016324575.

E-mail address: Thomas.Parmentier@bio.kuleuven.be (T. Parmentier). 
Diversität der Gemeinschaft beeinflussten. Schließlich waren die Myrmekophilengemeinschaften der beiden nah verwandten Waldameisenarten $F$. rufa und $F$. polyctena sehr ähnlich. Insgesamt zeigen unsere Ergebnisse in Übereinstimmung mit der Metapopulationstheorie, dass isolierte Nesthaufen weniger Myrmekophilenarten beherbergen. Diverse Metagemeinschaften von Ameisengästen treten auch in kleinen Waldameisenpopulationen mit gut vernetzten Nesthaufen auf. Wir diskutieren das große Potential von Ameisennestern und insbesondere der Nesthaufen von Roten Waldameisen für Forschungen zu Metapopulationen und Metagemeinschaften.

(C) 2015 Gesellschaft für Ökologie. Published by Elsevier GmbH. All rights reserved.

Keywords: F. rufa group; Myrmecophiles; Symbionts; Isolation; Metacommunity; Metapopulation; Ant guests

\section{Introduction}

A diverse group of arthropods is strictly associated with ants (Hölldobler \& Wilson 1990). They benefit from the resources provided by their host and the homeostatic nest conditions. Myrmecophiles are confined to ant nests, but differ in degree of host specificity. While some species are restricted to one ant species or narrowly related species, others occur with different ant taxa and few even show no preference at all (Hölldobler \& Wilson 1990). Myrmecophiles live thus in small, spatially distinct and stable patches (= ant nests of associated host ant taxa) susceptible to colonization surrounded by a large landscape matrix unsuitable for colonization. Hence, the populations of myrmecophiles can be expected to be organized as metapopulations (sensu Hanski \& Gilpin 1991) wherein local dynamics in the ant nest interact with dispersal among the ant nest patches. When multiple myrmecophile species live in the same set of distinct ant nests, their community can be described as a community of metapopulations or a metacommunity (Hanski \& Gilpin 1991). Metapopulation theory has proven to be a successful concept to study fragmented populations connected through dispersal. A key prediction of metapopulation theory is that populations in small and isolated patches are more likely to get extinct because of smaller carrying capacities and smaller odds to get rescued by new colonisations. Consequently, those patches support fewer species at the metacommunity level. Local environmental characteristics of the patch have been demonstrated as a third factor to affect patch occupation probability in metapopulations (Chisholm, Lindo, \& Gonzalez 2011; Jeffries 2005; Ranius 2000; Thomas et al. 2001).

Because of their hidden life style, the distribution and abundance of myrmecophiles are unclear and likely underestimated. In this study, we investigate which (metapopulation) processes structure myrmecophiles associated with European red wood ants (Formica rufa group). Red wood ants are dominant and aggressive arthropod predators in European woodlands (Laakso \& Setälä 2000; Hawes, Stewart, \& Evans 2002; Skinner 1980). Still, many arthropods managed to evade ant aggression and live successfully in or around their nest mounds in one of the largest associations of arthropods including Coleoptera, Hymenoptera, Diptera,
Lepidoptera, Heteroptera, Isopoda, Collembola, Acari and Araneae (Parmentier, Dekoninck, \& Wenseleers 2014).

Two red wood ant species, Formica rufa and Formica polyctena, co-occur in western Flanders, Belgium (Dekoninck et al. 2010). Their populations are isolated units due to forest fragmentation. They vary considerably in size, but the majority of the populations is relatively small. Nest mounds differ in local ecological characteristics, size and relative position to other mounds of the site. Nests persist likely by budding or by accepting related new queens (pers. observations). Those distinct and small red wood ant sites are thus ideal subjects to test factors classically structuring the dynamics and affecting the composition and richness of metapopulations and metacommunities.

Studies in large forest complexes in Finland by Päivinen, Ahlroth, Kaitala, and Suhonen (2004) and Härkönen and Sorvari (2014) demonstrated that isolation of mounds of the red wood ants $F$. aquilonia and $F$. polyctena negatively affected the diversity of myrmecophiles. Lower beetle diversity was also demonstrated in smaller mounds (Päivinen et al. 2004). These findings agree thus with metapopulation theory. Yet, it is not understood whether the same processes structure myrmecophile metacommunities in highly fragmented and impoverished, small, red wood ant sites. Moreover, it remains unknown whether local patch (i.e. mound) characteristics and factors at a larger spatial scale affect myrmecophile metacommunities. Therefore, we want to test in-depth potential factors structuring the myrmecophile metacommunity in fragmented red wood ant sites. More specifically, we assess the effect of site, isolation and multiple mound characteristics (size, $\mathrm{pH}$, moisture, host ant) on: (a) myrmecophile metacommunity composition and (b) myrmecophile species richness.

\section{Materials and methods}

\section{Study area}

The study area is situated in northwest Belgium (province: Western Flanders) (Fig. 1). This is a highly urbanized region with only few fragmented woodland patches remaining. Two red wood ant species, Formica rufa Linnaeus, 1761 and 


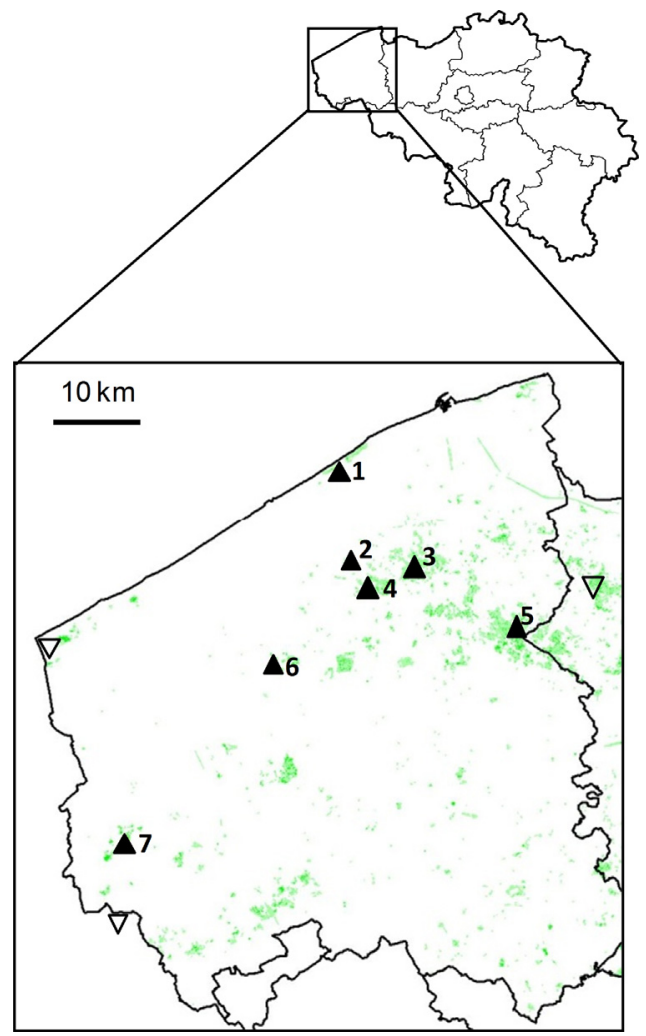

Fig. 1. Overview of red wood ant sites $(1=$ De Haan, $2=$ Roksem, $3=$ Beisbroek, $4=$ Aartrijke, 5= Beernem, 6= Vladslo, 7= West Vleteren) in West Flanders, the westernmost province of Belgium. Unsampled red wood ant sites in West Flanders and nearby regions are indicated by inverted open triangles. The mapped sites comprise all red wood ant mounds in this area. Forest fragments indicated in gray/green (online version). Detailed maps per site see Appendix A.

Formica polyctena Förster, 1850 persist in those isolated and small forests (Dekoninck, Vankerkhoven, \& Maelfait 2003). The two ant species are closely related and are even known to hybridize (Seifert, Kulmuni, \& Pamilo 2010). They can be distinguished based on degree of pilosity. Moreover they tend to have different ecological preferences (Seifert 2007). Formica rufa usually forms monodomous (one mound per colony) and monogynous (one queen) colonies along forest edges, while most $F$. polyctena colonies are polydomous (multiple mounds in a colony) and polygynous (multiple queens in a mound) typically established in inner forests (Seifert 2007). However, in the study area these differences are less clear-cut with $F$. rufa often forming strong polygynous and polydomous colonies and with $F$. polyctena mounds regularly lining forest edges (pers. observations; Dekoninck et al. 2010). Nevertheless, the two species can unambiguously be separated based on their pilosity and no hybrids occur in the study area.

We surveyed 83 mounds ( $29 \mathrm{~F}$. rufa, $54 \mathrm{~F}$. polyctena) in seven red wood ant sites and recorded the presence of myrmecophiles (Fig. 1) (detailed maps per site in Appendix A). Two sites (West-Vleteren, Vladslo) support Formica rufa, three
Formica polyctena (Beernem, Roksem, Aartrijke) and in the two remaining sites (De Haan and Beisbroek) both species occur sympatrically. We use the word "site" to describe a population of $F$. rufa and/or F. polyctena in a particular forest complex.

The distribution of the red wood ant mounds in the study area was already well recorded during previous studies (Dekoninck et al. 2010; Loones et al. 2008; Parmentier 2010) Additionally, the woodlands were intensively scanned prior to sampling to record new, moved or disappeared nests. Therefore we were able to map all nest mounds of the seven sites.

\section{Inventory of myrmecophiles and nest mound variables}

During the summer of 2012 and 2013, we collected all myrmecophiles in a 2 -L nest sample by successively inspecting small portions of that sample spread out in a large white tray. Afterwards, nest material, ants and their brood were gently put back into the nest to minimize disturbance. The 2L samples were taken from the central core of the 83 mounds. Beetles were identified following Freude, Harde, and Lohse (1964); Freude, Harde, and Lohse (1974), spiders following Roberts (2001). We identified 13 beetle species (including 8 rove beetles), two spiders, one springtail and one isopod.

For each mound we recorded the following variables: host species, site size, mound size, isolation, moisture and $\mathrm{pH}$. The host ant species was either $F$. rufa or $F$. polyctena. The seven red wood ant sites were assigned to two size classes based on total number of red wood ant mounds (small: $<15$ mounds, large: $25-48$ mounds). There was a large variation in mound height (and mound depth) corresponding rather with sun exposure than with colony size. Therefore we used nest surface (ellipse: $\pi a b / 4$ with $a, b$ the largest and smallest diameter of the mound) following Liautard, Brown, Helms, and Keller (2003) who demonstrated that this is a good measure for mound size and productivity in mound building ants. Dispersal distance and frequency is species specific and isolation for several species in one study system is consequently difficult to quantify with one parameter (Kindlmann \& Burel 2008). Therefore mound isolation was estimated as the sum of the surface areas of other nest mounds within a $100-\mathrm{m}$ radius $\left(S_{100}\right)$ of the focal nest mound or by the nearest neighbor distance $\left(d_{\min }\right)$. An additional nest sampling of the central core was done to measure environmental variables. These samples (ca. $10 \mathrm{~g}$ ) were collected after three consecutive dry days during the summer and brought to the lab. PH was recorded (Lutron sensor PH-223) on 1:5 soil suspensions. Additionally soil samples were dried overnight at $60{ }^{\circ} \mathrm{C}$ in an oven (Memmert) to quantify moisture content gravimetrically.

The possible host ant species of the observed myrmecophiles are listed in Table 1. The main secondary hosts are Lasius fuliginosus, Formica sanguinea, Lasius brunneus and Formica fusca. F. fusca was observed interspersed among the 
Table 1. List of observed species, total recorded individuals (N), mean number of individuals (Mean), proportion of occupied nests (\%), maximum number of individuals found in a 2-L sample (Max). Host: myrmecophile associated with host Formica rufa (R) and/or Formica polyctena $(\mathrm{P})$ in this study, Literature hosts: other host ant species occurring in the study area based on Parmentier et al. $(2014)$, RWA $=$ red wood ant species, Ffusc = Formica fusca, Fsang = Formica sanguinea, Lfuli =Lasius fuliginosus, Lbrun = Lasius brunneus, Lflav =Lasius flavus, L sp. = Lasius species.

\begin{tabular}{|c|c|c|c|c|c|c|}
\hline Species & $N$ & Mean & $\%$ & Max & Host & Literature hosts \\
\hline \multicolumn{7}{|l|}{ Coleoptera } \\
\hline \multicolumn{7}{|l|}{ Staphylinidae } \\
\hline Stenus aterrimus Erichson, 1839 & 17 & 0.20 & 16.5 & 2 & $\mathrm{R}+\mathrm{P}$ & RWA \\
\hline Thiasophila angulata (Erichson, 1837) & 131 & 1.56 & 54.1 & 22 & $\mathrm{R}+\mathrm{P}$ & RWA/Fsang/Lfuli/Lbrun \\
\hline Nothotecta flavipes (Gravenhorst, 1806) & 12 & 0.14 & 11.8 & 2 & $\mathrm{R}+\mathrm{P}$ & RWA/Fsang/Lflav \\
\hline Lyprocorrhe anceps (Erichson, 1837) & 46 & 0.55 & 18.8 & 16 & $\mathrm{R}+\mathrm{P}$ & RWA/Lfuli \\
\hline Amidobia talpa (Heer, 1841) & 106 & 1.26 & 32.9 & 36 & $\mathrm{R}+\mathrm{P}$ & RWA/Lfuli \\
\hline Dinarda maerkelii Kiesenwetter, 1843 & 10 & 0.12 & 10.6 & 2 & $\mathrm{R}+\mathrm{P}$ & RWA/Fsang \\
\hline Quedius brevis Erichson, 1840 & 7 & 0.08 & 7.1 & 2 & $\mathrm{R}+\mathrm{P}$ & RWA/LFuli/Lbrun/Fsang \\
\hline Leptacinus formicetorum Märkel, 1841 & 119 & 1.42 & 35.3 & 16 & $\mathrm{R}+\mathrm{P}$ & RWA/Lbrun \\
\hline \multicolumn{7}{|l|}{ Chrysomelidae } \\
\hline Clytra quadripunctata (Linnaeus, 1758) & 159 & 1.89 & 45.9 & 23 & $\mathrm{R}+\mathrm{P}$ & RWA/Ffusc/Fsang \\
\hline \multicolumn{7}{|l|}{ Monotomidae } \\
\hline Monotoma angusticollis (Gyllenhal, 1827) & 114 & 1.37 & 47.1 & 16 & $\mathrm{R}+\mathrm{P}$ & RWA \\
\hline Monotomaconicicollis(Gyllenhal, 1827) & 39 & 0.47 & 21.2 & 5 & $\mathrm{R}+\mathrm{P}$ & RWA \\
\hline \multicolumn{7}{|l|}{ Histeridae } \\
\hline Myrmetes paykulli Kanaar, 1979 & 14 & 0.17 & 15.3 & 2 & $\mathrm{R}+\mathrm{P}$ & RWA/(L sp.) \\
\hline Dendrophilus pygmaeus (Linnaeus, 1758) & 2 & 0.02 & 3.5 & 1 & $\mathrm{P}$ & RWA/Lfuli \\
\hline \multicolumn{7}{|l|}{ Araneae } \\
\hline Thyreosthenius biovatus (O. P.-Cambridge, 1875) & 450 & 5.36 & 80.0 & 24 & $\mathrm{R}+\mathrm{P}$ & RWA/(Ffusc) \\
\hline Mastigusa arietina (Thorell, 1871) & 26 & 0.31 & 10.6 & 7 & $\mathrm{P}$ & RWA/Lfuli/Lbrun/Ffusc \\
\hline \multicolumn{7}{|l|}{ Isopoda } \\
\hline Platyarthrus hoffmannseggi Brandt, 1833 & 259 & 3.1 & 16.5 & 109 & $\mathrm{R}+\mathrm{P}$ & All ants \\
\hline \multicolumn{7}{|l|}{ Collembola } \\
\hline Cyphoderus albinus Nicolet, 1842 & 4500 & 54.2 & 91.8 & 1362 & $\mathrm{R}+\mathrm{P}$ & All ants \\
\hline
\end{tabular}

red wood ant sites of De Haan, Beisbroek and Roksem but in very low densities. F. sanguinea was only recorded at the edge of the site in Beisbroek and L. fuliginosus at the edge of Beisbroek and De Haan. Those nests were located farther than $100 \mathrm{~m}$ from the nearest red wood ant mound. L. brunneus was not observed near the red wood ant sites. Therefore we assume that the used isolation proxies calculated from only red wood ant mounds are accurate estimations for most myrmecophiles. Exceptions are the "pan"myrmecophilous species Platyarthrus hoffmannseggi and Cyphoderus albinus which also thrive in ant nests of common species (belonging to the genera Lasius, Myrmica, Leptothorax and Tetramorium) found in all red wood ant sites.

\section{Data analyses}

\section{Multivariate analysis}

In this analysis we were interested which factors structured the myrmecophile community as a whole and assessed their relative importance. Hence, we examined which variables could affect the species composition in a myrmecophile community. We grouped the independent variables in three subsets: (a) nest mound variables (=moisture, $\mathrm{pH}$, nest size, ant species), (b) within-site isolation variables $\left(=S_{100}\right.$ and $d_{\text {min }}$ ), and (c) site variables (site size and site identity). For every category, we ran an RDA (Redundancy Analysis) with the presence-absence data of myrmecophile species as dependent community matrix. Then we selected a minimal number of significant variables by applying the foward.sel function in $\mathrm{R}$ package packfor for the three subsets of variables. Thereafter we applied variation partitioning following the methods of Peres-Neto, Legendre, Dray, and Borcard (2006) with the varpart function in the R package vegan. In this approach, the total variation (expressed in $R^{2}$ ) explained by the model is partitioned into unique and shared fractions of the subsets of predictors. Adjusted $R^{2}$ values were calculated for each fraction and provide unbiased estimates of the variation explained by those fractions (Peres-Neto et al. 2006). The significances of the fractions were tested by a permutation test $(n=1000)$ using the function ANOVA. Significant variables were plotted on an unconstrained Principal 
Component Analysis (PCA) with the presence-absence data as community matrix. $D_{\min }$ and mound size were $\ln$ transformed and $S_{100}$ was square rooted. Continuous variables were centered and divided by their standard deviations.

\section{Univariate analysis}

In this analysis, we analyzed the effect of multiple variables on the number of myrmecophile species found. Predictor variables (moisture, $\mathrm{pH}$, mound size, ant species, isolation, site size and site) were regressed with (a) total species richness, (b) Staphylinidae species richness and (c) restricted myrmecophyle species richness (total species richness minus the panmyrmecophilous species $C$. albinus and $P$. hoffmannseggi), per $2 \mathrm{~L}$ volume fitting poisson generalized models with log link function. Goodness-of-fit tests based on likelihood ratio confirmed that models were Poisson error distributed.

We used the dredge function (package MuMIn) to rank models based on AICc (corrected Akaike's Information Criteria). The model with the lowest AICc was considered the model with the best support ('best model'). Other models for which the AICc difference ( $\triangle \mathrm{AICc}$ ) with the best model were $\leq 2$, are argued to have substantial support as well and were selected with the best model (Burnham \& Anderson 2002). We calculated Akaike weights (wi) for those models, which represent the relative probability (ranging from 0 to 1 ) that a model is the best among the subset of candidate models. We used a model-averaging approach to estimate averages, standard errors and confidence intervals of parameters for the selected set of models. Estimates were weighted by the model's Akaike Weight (Burnham \& Anderson 2002). Confidence intervals of those model-averaged estimates excluding 0 are significant at the $\alpha=0.05$ level (Nakagawa \& Cuthill 2007). In addition, we tested significance of factors of the 'best' models (lowest AICc) with Type II likelihood ratio tests using function ANOVA in R package car.

Mound size was $\ln$ transformed and $S_{100}$ was square rooted. Continuous variables were centered and divided by their standard deviations. Sites were nested within site size classes in our models. We used $S_{100}$ (total nest surface of other mounds within a radius of $100 \mathrm{~m}$ ) as proxy for isolation in these univariate analyses. The effect of isolation on species richness was similar when employing $d_{\min }$ (nearest distance to other mound) as isolation measure, but models had higher AICc-values.

\section{Results}

\section{Distribution}

Table 1 shows the mean abundances and proportions of nests occupied per species and indicates whether the myrmecophile was found with $F$. rufa, F. polyctena or both. Almost all myrmecophiles were observed with both host ant species. Exceptions were the spider Mastigusa arietina and the histerid beetle Dendrophilus pygmaeus, which both only occurred with $F$. polyctena. This is likely caused by the small number of individuals recorded (26 and 2 , respectively). The most abundant species is the ant springtail Cyphoderus albinus, which occurred in more than $90 \%$ of the ant nests. This species can reach enormous abundances up to 1362 individuals per 2-L sample. The spider Thyreosthenius biovatus and the rove beetle Thiasophila angulata were also recorded in more than $50 \%$ of the sampled nests. The spider Thyreosthenius biovatus was only recorded three times in Belgium (pers. communication Dr. L. Baert). Yet, we found this spider in $80 \%$ of the mounds and in all sampled red wood ant sites.

Table 2 gives an overview of the seven red wood ant sites: number of mounds, average species richness and number of red wood ant specific myrmecophiles (Stenus aterrimus, Dinarda maerkelii, Clytra quadripunctata, Monotoma angusticollis, Monotoma conicicollis, Thyreosthenius biovatus) in the study region. In the larger sites, more myrmecophile species were detected. This is a sampling effect (cf. number of sampled mounds), because average species richness per mound in small sites equals that of large sites. Red wood ant specific myrmecophiles also occur in the smallest and highly isolated red wood ant sites (Fig. 1). On average, there was a comparable diversity of those red wood ant specifics in large and small sites (Table 2).

\section{Multivariate analysis}

Forward selection of the mound characteristics subset retained the variables moisture, $\mathrm{pH}$ and host species. $S_{100}$ and $d_{\min }$ of the within-site isolation subset were both selected. Site identity was selected, but site size was eliminated from the site subset. Fig. 2 illustrates the explained variation (based on adjusted $R^{2}$ values) of the myrmecophile community by the different subsets. Explained variation (12.9\%) was relatively low, indicating that random processes and possibly unrecorded variables have a large effect on species composition. Pure within-site isolation (isolation conditioned for site and mound characteristics) (explained variation $=2.4 \%$, $P=0.002$ ) and pure site identity (conditioned for isolation and mound characteristics) (explained variation $=4.4 \%$, $P=0.004)$ structured significantly the myrmecophile community. Pure mound characteristics (conditioned for isolation and site identity) $(P=0.151)$ had no effect on the composition of the myrmecophile community. Mound characteristics in particular sites also explained a large fraction (3.6\%). The PCA plot depicts that most myrmecophiles are correlated with increasing $S_{100}$ and/or decreasing $d_{\text {min }}$, so their occurrence increases with decreasing isolation (Fig. 3). Mounds of different sites are not separated in distinct clusters, but show some structuring corresponding with the results of variation partitioning. Mounds of large red wood ant sites are similar in species composition to those of small red wood ant sites (95\% confidence ellipses overlapping). The species composition of the community associated with $F$. rufa is only slightly different from (95\% confidence ellipses slightly distinct) the community associated with $F$. polyctena. These differences 
Table 2. Red wood ant (RWA) site size (indicated by number of mounds), number of sampled mounds and total species richness and average species richness per mound of myrmecophiles and myrmecophiles specific to red wood ants (Thyreosthenius biovatus, Monotoma angusticollis, Monotoma conicicollis, Clytra quadripunctata, Stenus aterrimus and Dinarda maerkelii).

\begin{tabular}{lllllll}
\hline Site & $\begin{array}{l}\text { Total } \\
\text { mounds }\end{array}$ & $\begin{array}{l}\text { Sampled } \\
\text { mounds }\end{array}$ & $\begin{array}{l}\text { Total } \\
\text { species }\end{array}$ & $\begin{array}{l}\text { Total species } \\
\text { specific to } \\
\text { RWAs }\end{array}$ & $\begin{array}{l}\text { Average } \\
\text { species } \pm \text { SE }\end{array}$ & $\begin{array}{l}\text { Average species } \\
\text { specific to } \\
\text { RWAs } \pm \text { SE }\end{array}$ \\
\hline Beernem & 49 & 20 & 16 & 5 & $5.30 \pm 0.58$ & $1.70 \pm 0.30$ \\
West-Vleteren & 37 & 20 & 15 & 6 & $5.60 \pm 0.49$ & $2.65 \pm 0.25$ \\
Beisbroek & 27 & 19 & 15 & 6 & $6.21 \pm 0.38$ & $2.05 \pm 0.27$ \\
De Haan & 14 & 11 & 13 & 5 & $4.75 \pm 0.39$ & $2.36 \pm 0.32$ \\
Roksem & 10 & 8 & 8 & 2 & $5.67 \pm 0.27$ & $2.25 \pm 0.29$ \\
Aartrijke & 3 & 3 & 5 & $5.50 \pm 0.19$ & $3.00 \pm 0.71$ \\
Vladslo & 2 & 2 & 10 & & 5.00 & 0.79 \\
\hline
\end{tabular}

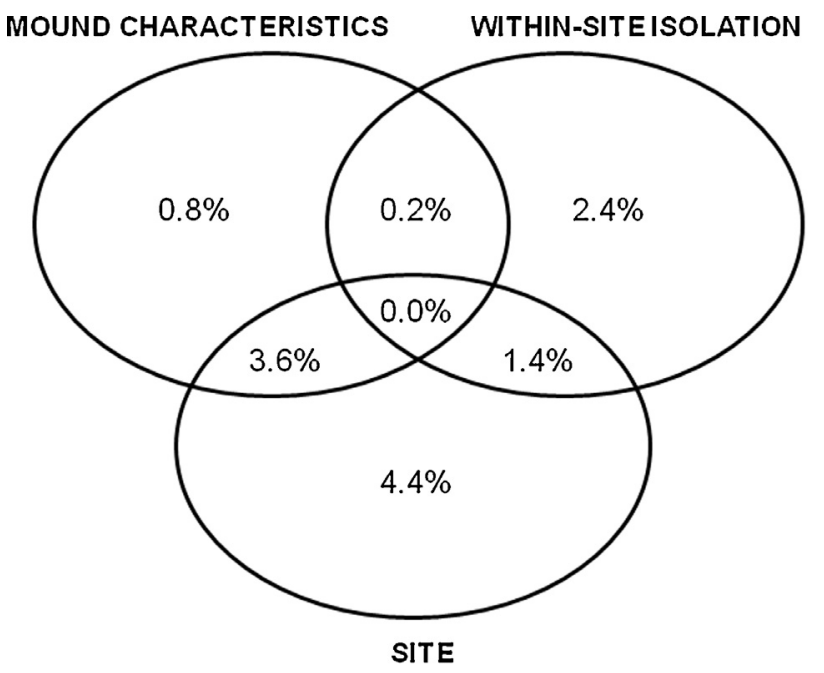

RESIDUALS $87.1 \%$

Fig. 2. Variation partitioning based on adjusted $R^{2}$. Total variation is $100 \%$ and numbers represent proportions of explained variation by each fraction. Mound characteristics subset $=\mathrm{pH}$, moisture, host, within-site isolation subset $=d_{\min }$ and $S_{100}$, site subset $=$ site identity.

could result from the correlation between site and host ant species, i.e. some sites supported one red wood ant or had a majority of one species. Therefore site differences in myrmecophile prevalence could cause differences in host species preference. In the variation partitioning analysis, this variation could be captured by the fraction shared by site and mound characteristics.

\section{Univariate analysis}

Table 3 reports the selected set of models for which $\Delta \mathrm{AICc} \leq 2$. The best model explaining either (a) total species richness, (b) Staphylinidae richness or (c) restricted myrmecophile species richness (total species richness minus the panmyrmecophilous species $C$. albinus and $P$. hoffmannseggi), was a model with an intercept and only the predictor variable $S_{100}$ incorporated. Other well supported models $(\triangle \mathrm{AICc} \leq 2)$ always incorporated $S_{100}$ and one other predictor variable. Parameter averaging across those models

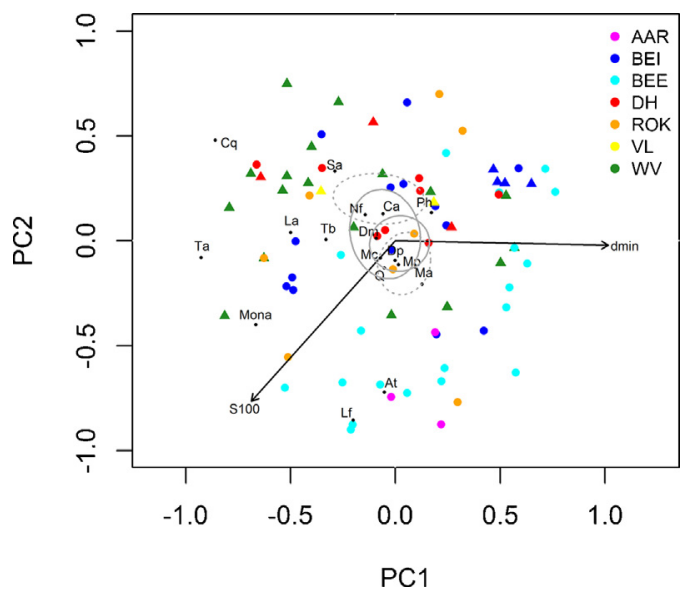

Fig. 3. PCA diagram with species, mounds and significant variables of RDA analyses plotted. Mounds are sorted according to host ant species $(F$. rufa $=$ triangle, $F$. polycten $a=$ circle $)$ and site (different colors). Isolation decreases with higher $S_{100}$ but increases with higher $d_{\min }$. Most species are positively correlated with $S_{100}$ and/or negatively with $d_{\min }$. At=Amidobia talpa, $\mathrm{Cq}=$ Clytra quadripunctata, $\mathrm{Ca}=$ Cyphoderus albinus, Dend = Dendrophilus pygmaeus, Dm=Dinarda maerkelii, Lf=Leptacinus formicetorum, La=Lyprocorrhe anceps, Ma=Mastigusa arietina, Mona=Monotoma angusticollis, $\mathrm{Mc}=$ Monotoma conici collis, $\mathrm{Mp}=$ Myrmetes paykulli, $\mathrm{Nf}=$ Notothecta flavipes, $\mathrm{Ph}=$ Platyarthrus hoffmannseggi, $\mathrm{Q}=$ Quedius brevis, $\mathrm{Sa}=$ Stenus aterrimus, $\mathrm{Ta}=$ Thiasophila angulata, $\mathrm{Tb}=$ Thyreosthenius biovatus. Host ant species $95 \%$ confidence ellipses indicated with gray dotted ellipses: upper ellipse $F$. rufa, lower ellipse $F$. polyctena. Site size $95 \%$ confidence ellipses indicated with gray full ellipses: left ellipse small site, right ellipse large site.

for which $\triangle \mathrm{AICc} \leq 2$ and respectively explaining (a) total species richness, (b) Staphylinidae richness or (c) restricted myrmecophile species richness is given in Table 4 . For the three species richness measures, only the $95 \%$ CIs of $S_{100}$ do not encompass 0 . This indicates that this factor is significant in the averaged model. The relationship between increasing $S_{100}$ and species richness of total myrmecophiles, Staphylinidae and restricted myrmecophiles is given in Fig. 4. The $S_{100}$ effect size is higher for restricted myrmecophile richness 
Table 3. Overview of model selection for models explaining (a) total myrmecophile species richness, (b) Staphylinidae species richness and (c) restricted myrmecophile species richness (total species richness minus the panmyrmecophilous species $C$. albinus and $P$. hoffmannseggi). Models are ranked from the lowest AICc value (="best' model) to higher AICc values (decreasing likelihood). Only models with $\Delta$ AICc $\leq 2$ are selected. Akaike's weight (wi) indicate the likelihood of a model, given the set of models being considered (Burnham \& Anderson 2002).

\begin{tabular}{|c|c|c|c|c|c|}
\hline Species richness & Model & $\mathrm{df}$ & $\mathrm{AICc}$ & $\Delta \mathrm{AICc}$ & wi \\
\hline \multirow[t]{4}{*}{ (a) Total } & $($ intercept $)+S_{100}$ & 2 & 349.78 & 0.00 & 0.35 \\
\hline & (intercept) $+S_{100}+\mathrm{pH}$ & 3 & 350.50 & 0.71 & 0.25 \\
\hline & (intercept) $+S_{100}+$ moisture & 3 & 350.51 & 0.73 & 0.25 \\
\hline & $($ intercept $)+S_{100}+$ site size & 3 & 351.47 & 1.69 & 0.15 \\
\hline \multirow[t]{3}{*}{ (b) Staphylinidae } & (intercept) $+S_{100}$ & 2 & 270.3 & 0.00 & 0.54 \\
\hline & $($ intercept $)+S_{100}+$ moisture & 3 & 271.8 & 1.52 & 0.25 \\
\hline & (intercept) $+S_{100}+$ mound size & 3 & 272.2 & 1.91 & 0.21 \\
\hline \multirow[t]{4}{*}{ (c) Restricted myrmecophiles } & $($ intercept $)+S_{100}$ & 2 & 343.12 & 0.00 & 0.38 \\
\hline & (intercept) $+S_{100}+$ moisture & 3 & 343.66 & 0.54 & 0.29 \\
\hline & $($ intercept $)+S_{100}+\mathrm{pH}$ & 3 & 344.52 & 1.40 & 0.19 \\
\hline & $($ intercept $)+S_{100}+$ site size & 3 & 345.04 & 1.91 & 0.15 \\
\hline
\end{tabular}

compared with total species richness (Table 4). The effect of isolation is hence lower on species richness when also considering the panmyrmecophilous species. This is logical because C. albinus and P. hoffmannseggi also occupy nests of other ant species among the nest mounds in the study sites. Staphylinidae species richness is more severely affected by isolation compared with the average effect of isolation on restricted myrmecophiles. The factor $S_{100}$ was also highly significant

Table 4. Overview of model-averaged estimates for the log linear Poisson regression models explaining the log of the response variables: (a) total myrmecophile species richness, (b) Staphylinidae species richness and (c) restricted myrmecophile species richness. Estimates are averaged for all models with $\Delta$ AICc $\leq 2$ and weighted by each model's Akaike weigth (wi). Relative variable importance ( $w_{\text {ip }}$ ) of a particular variable is the sum of all wi's of models incorporating that variable. Isolation decreases with higher $S_{100}$. Thus positive $S_{100}$ slopes correspond with higher diversity in less isolated mounds. $95 \% \mathrm{CI}$ of predictors not encompassing 0 are given in bold.

\begin{tabular}{|c|c|c|c|c|}
\hline Species richness & Predictor variable & Estimate & $95 \% \mathrm{CI}$ & $w_{\text {ip }}$ \\
\hline \multirow[t]{8}{*}{ (a) Total } & (Intercept) & 1.62 & 1.52 to 1.72 & \\
\hline & $S_{100}$ & 0.14 & 0.05 to 0.24 & 1.00 \\
\hline & Moisture & -0.02 & -0.16 to 0.04 & 0.25 \\
\hline & $\mathrm{pH}$ & 0.02 & -0.04 to 0.17 & 0.25 \\
\hline & Host ant & & & \\
\hline & Mound size & & & \\
\hline & Site size & 0.01 & -0.14 to 0.29 & 0.15 \\
\hline & Site & & & \\
\hline \multirow[t]{8}{*}{ (b) Staphylinidae } & (Intercept) & 0.55 & 0.38 to 0.72 & \\
\hline & $S_{100}$ & 0.33 & 0.16 to 0.49 & 1.00 \\
\hline & Moisture & -0.02 & -0.24 to 0.10 & 0.25 \\
\hline & $\mathrm{pH}$ & & & \\
\hline & Host ant & & & \\
\hline & Mound size & -0.01 & -0.22 to 0.14 & 0.21 \\
\hline & Site size & & & \\
\hline & Site & & & \\
\hline \multirow[t]{8}{*}{ (c) Restricted myrmecophiles } & (Intercept) & 1.37 & 1.25 to 1.48 & \\
\hline & $S_{100}$ & 0.20 & 0.09 to 0.31 & 1.00 \\
\hline & Moisture & -0.02 & -0.18 to 0.04 & 0.29 \\
\hline & $\mathrm{pH}$ & 0.01 & -0.07 to 0.17 & 0.19 \\
\hline & Host ant & & & \\
\hline & Mound size & & & \\
\hline & Site size & 0.01 & -0.18 to 0.30 & 0.15 \\
\hline & Site & & & \\
\hline
\end{tabular}



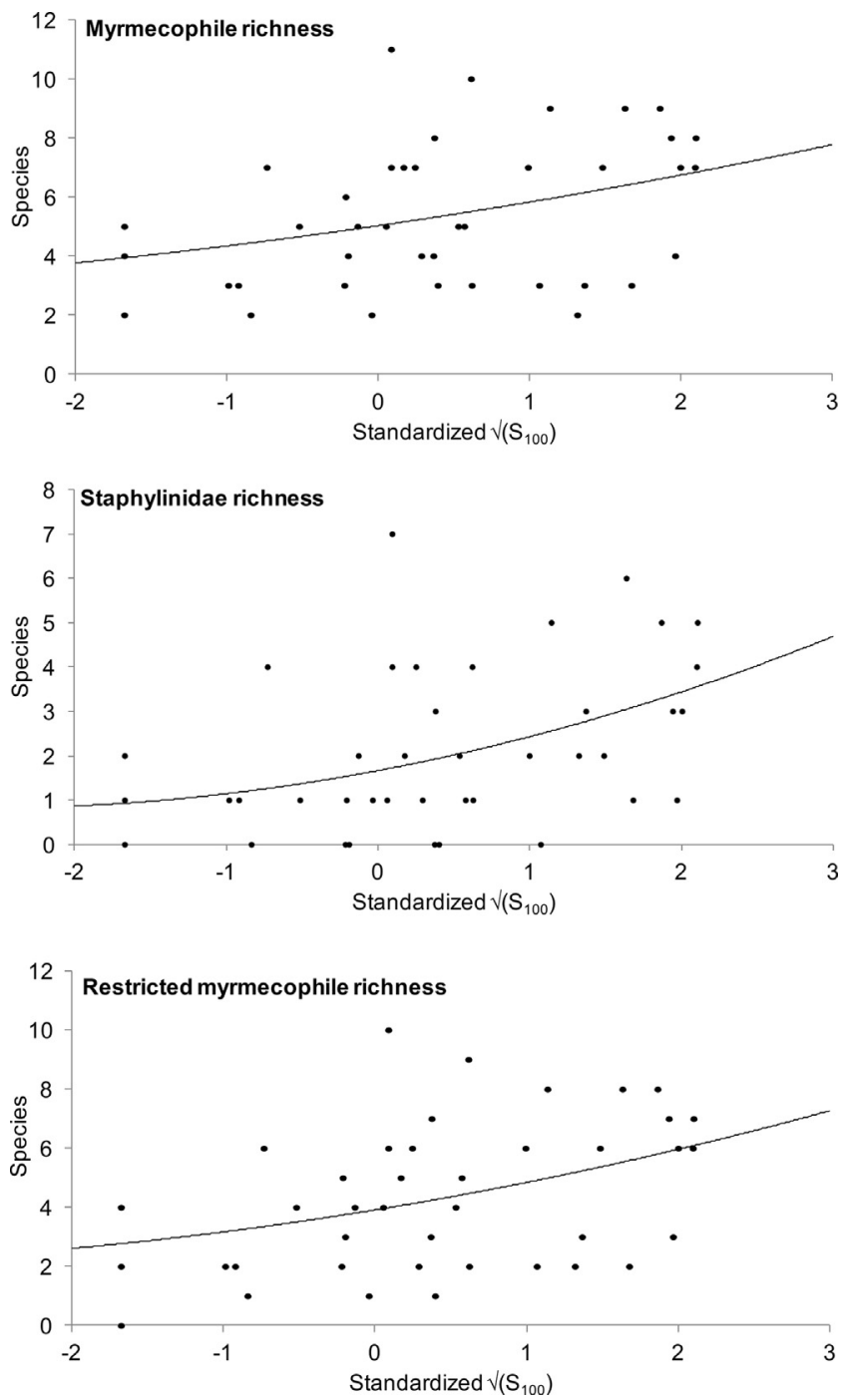

Fig. 4. Relationship between increasing $S_{100}$ (increasing amount of nest surface of other mounds within 100 meters $=$ decreasing isolation) and species richness of total myrmecophiles, Staphylinidae and restricted myrmecophiles (=total myrmecophile species richness minus panmyrmecophilous Cyphoderus albinus and Platyarthrus hoffmannseggi). Fitted models are based on model-averaged coefficients.

in the 'best' models (lowest AICc) with only $S_{100}$ as predictor variable ((a) total species richness: $P=0.005$, (b) Staphylinidae species richness: $P<0.001$ (c) restricted myrmecophile species richness: $P<0.001$ ).

\section{Discussion}

Our study demonstrates that severely fragmented wood ant populations still support a relatively diverse group of myrmecophiles. We found in this study 17 obligate myrmecophile species including six specialist red wood ant associates. Studies in large forest complexes in Finland recorded a similar diversity: Päivinen et al. (2004) found 16 beetle species in
49 mounds of $F$. aquilonia, Härkönen and Sorvari (2014) reported 22 myrmecophiles in 12 mounds with $F$. polyctena. In this study, $F$. rufa and $F$. polyctena did not differ in total myrmecophile species richness and staphylinid species richness and their community composition was similar. The myrmecophiles in this study are also associated with other red wood ant species (F. lugubris, F. aquilonia, F. pratensis) suggesting that the myrmecophile community is probably similar for all six European red wood ants (Lapeva-Gjonova \& Lieff 2012; Päivinen et al. 2004; Parmentier et al. 2014; Robinson \& Robinson 2013).

\section{Red wood ant mounds as patches in a myrmecophile metapopulation/metacommunity}

Myrmecophiles perceive ant nests as small suitable patches distributed in a hostile landscape matrix. In the studied sites, red wood ant mound distribution is highly heterogeneous ranging from highly isolated to well connected and ultimately to polydomous aggregations. In accordance with the predictions of metapopulation theory, we found very strong evidence that myrmecophile and rove beetle diversity was positively correlated with mound connectivity. These results are akin to Päivinen et al. (2004) and Härkönen and Sorvari (2014) who reported a negative correlation between myrmecophile diversity and nest isolation in $F$. aquilonia and $F$. polyctena. Variance partitioning demonstrated that among site differences explained more variation in the myrmecophile community than within-site isolation. This suggests that processes at a larger spatial scale than the myrmecophile metacommunity in a particular red wood ant site are important as well. These processes could include the spatial distribution and isolation of the sites (i.e. myrmecophiles are organized in a metacommunity of metacommunities). Site isolation, however, is hard to estimate as most species occur with more general ant species as well.

Larger patches can support larger populations and are more likely to be colonized in metapopulation models. Therefore large patches have a higher occupation probability in classical metapopulation models (Hanski 1994). In contrast with Päivinen et al. (2004) we did not find a relationship between mound size and diversity or prevalence. However, we sampled a fixed amount of nest material from all nests, rather than the whole mound. So we measured density rather than population sizes. Therefore total species richness and population sizes are probably higher in large nests.

Local patch characteristics have been demonstrated as a third factor affecting metapopulation and metacommunity dynamics (Jeffries 2005; Ranius 2000; Thomas et al. 2001). Moisture and $\mathrm{pH}$ are two key abiotic variables that structure the soil arthropod community and might thus determine the quality of wood ant mounds for myrmecophiles as well (Giller 1996). Generally, dry and/or acid soils tend to have lower diversity and abundances of soil fauna (Giller 1996; Tsiafouli et al. 2005). Additionally, there are indications 
of differential niche preference amongst soil organisms, whereby related species favor different conditions along the soil pH and soil moisture gradients (Giller 1996; van Straalen $\&$ Verhoef 1997). The sampled red wood ant mounds varied considerably in acidity (pH: 3.10-6.33) and moisture content $(5-67 \%)$, but this had no effect on total diversity or community composition.

Metapopulations need a minimum number of patches for long-term persistence, commonly referred to as the minimum viable metapopulation size (MVM) (Hanski, Moilanen \& Gyllenberg, 1996). A key result of this study is that (very) small and isolated red wood ant populations can have a very diverse myrmecophile community, suggesting that MVM is low for red wood ant myrmecophiles. This can be partly explained by other ant host nests which can serve as stepping stones. However, alternative host ant nests were rare for most myrmecophiles. Moreover red wood ant specific myrmecophiles such as T. biovatus and M. angusticollis were also found in the small red wood ant sites, indicating that those myrmecophiles could persist in very small metapopulations. A red wood ant mounds provide a warm and moist environment with plenty of food resources (Frouz, Kalcik, \& Cudlín, 2005; Rosengren et al. 1987; Skinner 1980). Moreover, large numbers of queens occur in single mounds and regularly new mounds bud from the nest (pers. observations TP). Therefore the extinction risk of the mound, colony and population at a larger scale is relative low without major disturbances. Hence, a small number of highly connected mounds might support small, stable myrmecophile metapopulations for a long period.

\section{Ant nests and their associates as terrestrial model systems in metapopulation and metacommunity research}

Ant nests provide suitable systems to test metapopulation and metacommunity theory. Nests of ants are clearly delineated islands in a matrix of unsuitable habitat for obligate myrmecophiles. Therefore "patch" dimensions, "patch" isolation and connectivity measures are easy to quantify. Because of their small size, homogenous and representative samples can be easily collected and rapidly extended to a large number of patches. Ant nests are abundant and many myrmecophiles or myrmecophile communities are widespread. This allows hypothesis testing on both a broad spatial scale (e.g. regional effects on metacommunity dynamics) and on a local scale (e.g. the effect of altitudinal and environmental variables on the metacommunity dynamics of panmyrmecophilous species when multiple hosts are available in a site). Ant nests vary in longevity and regularly new nests are founded independently or budded from other nests (e.g. red wood ant nest life span ranges from less than 1 year to more than 70 years (Gösswald 1989; Klimetzek 1981)). This nest dynamism facilitates the tracking of colonization, succession and competition (cf. competition-colonization trade-off).
Promising ant hosts to test metacommunity hypotheses are especially red wood ants (F. rufa group), Formica sanguinea and the shiny black wood ant Lasius fuliginosus. Their nests are easy to track, they have a wide distribution and they support a large diversity of species in one nest (Päivinen et al. 2003; Parmentier et al. 2014). Overall, the properties of ant nests correspond thus with classic theoretical metapopulations and metacommunities. They are valuable tools to broaden our knowledge on general questions in evolution and community functioning.

\section{Acknowledgements}

This project was supported by the FWOVlaanderen (Research Foundation Flanders) (grant TP no. 11D6414N). We are greatly indebted to two anonymous referees, managing editor Klaus Hövemeyer, Luc de Meester and Frederik Hendrickx for their helpful comments. M. Van Kerckvoorde assisted in beetle identification, L. Baert verified spider identification. We thank ANB for permission to take samples.

\section{Appendix A. Supplementary data}

Supplementary data associated with this article can be found, in the online version, at http://dx.doi.org/10.1016/ j.baae.2015.04.008.

\section{References}

Burnham, K. P., \& Anderson, D. R. (2002). Model selection and multimodel inference: A practical information-theoretic approach. Springer Science \& Business Media.

Chisholm, C., Lindo, Z., \& Gonzalez, A. (2011). Metacommunity diversity depends on connectivity and patch arrangement in heterogeneous habitat networks. Ecography, 34, 415-424. http://dx.doi.org/10.1111/j.1600-0587.2010.06588.x

Dekoninck, W., Vankerkhoven, F., \& Maelfait, J.-P. (2003). Verspreidingsatlas en voorlopige Rode Lijst van de mieren van Vlaanderen.

Dekoninck, W., Hendrickx, F., Grootaert, P., \& Maelfait, J.P. (2010). Present conservation status of red wood ants in north-western Belgium: Worse than previously, but not a lost cause. European Journal of Entomology, 107, 209-218. http://dx.doi.org/10.14411/eje.2010.028

Freude, H., Harde, K. W., \& Lohse, G. A. (1964). Käfer Mitteleuropas Bd 4. Staphylinidae I. Goecke and Evers Verlag: Krefeld.

Freude, H., Harde, K. W., \& Lohse, G. A. (1974). Käfer Mitteleuropas. Bd 5. Staphylinidae II. Krefeld: Goecke and Evers Verlag.

Frouz, J., Kalcik, J., \& Cudlín, P. (2005). Accumulation of phosphorus in nests of red wood ants Formica s. str. Annales Zoologici Fennici, 42, 269-275.

Giller, P. (1996). The diversity of soil communities, the poor mans tropical rainforest'. Biodiversity and Conservation, 168, 135-168. http://dx.doi.org/10.1007/BF00055827 
Gösswald, K. (1989). Die Waldameise. Band 1. Biologische Grundlagen, Ökologie und Verhalten. Wiesbaden: Aula-Verlag.

Hanski, I., \& Gilpin, M. (1991). Metapopulation dynamics: Brief history and conceptual domain. Biological Journal of the Linnean Society, 42, 3-16. http://dx.doi.org/10.1111/j.1095-8312. 1991.tb00548.x

Hanski, I. (1994). A practical model of metapopulation dynamics. Journal of Animal Ecology, 63, 151-162. http://dx.doi.org/ $10.2307 / 5591$

Hanski, I., Moilanen, A., \& Gyllenberg, M. (1996). Minimum viable metapopulation size. American Naturalist, 147, 527-541. http://dx.doi.org/10.1086/285864

Härkönen, S. K., \& Sorvari, J. (2014). Species richness of associates of ants in the nests of red wood ant Formica polyctena (Hymenoptera, Formicidae). Insect Conservation and Diversity, 7, 485-495. http://dx.doi.org/10.1111/icad.12072

Hawes, C., Stewart, A., \& Evans, H. (2002). The impact of wood ants (Formica rufa) on the distribution and abundance of ground beetles (Coleoptera: Carabidae) in a Scots pine plantation. Oecologia, 131, 612-619. http://dx.doi.org/10.1007/ s00442-002-0916-6

Hölldobler, B., \& Wilson, E. O. (1990). The ants. Harvard University Press Cambridge: Massachusetts.

Jeffries, M. (2005). Local-scale turnover of pond insects: Intra-pond habitat quality and inter-pond geometry are both important. Hydrobiologia, 543, 207-220. http://dx.doi.org/10.1007/ s10750-004-7452-9

Kindlmann, P., \& Burel, F. (2008). Connectivity measures: A review. Landscape Ecology, 879-890. http://dx.doi.org/10.1007/ s10980-008-9245-4

Klimetzek, D. (1981). Population studies on hill building woodants of the Formica-rufa-group. Oecologia, 48, 418-421. http://dx.doi.org/10.1007/BF00346504

Laakso, J., \& Setälä, H. (2000). Impacts of wood ants (Formica aquilonia Yarr.) on the invertebrate food web of the boreal forest floor. Annales Zoologici Fennici, 37, 93-100.

Lapeva-Gjonova, A., \& Lieff, O. (2012). Ant-associated rove beetles (Coleoptera: Staphylinidae) in Bulgaria. Acta Entomologica Slovenica, 20, 73-84.

Liautard, C., Brown, W. D., Helms, K. R., \& Keller, L. (2003). Temporal and spatial variations of gyne production in the ant Formica exsecta. Oecologia, 136, 558-564. http://dx.doi.org/ 10.1007/s00442-003-1300-x

Loones, J., Maelfait, J.-P., Van Rhijn, J., Dekoninck, W., \& Adriaens, T. (2008). De rode bosmier in Vlaanderen: voorkomen, bedreigingen en herstelmaatregelen aan de hand van een detailstudie in de Sixtusbossen (Poperinge-Vleteren). Rapporten van het Instituut voor Natuur- en Bosonderzoek.

Nakagawa, S., \& Cuthill, I. C. (2007). Effect size, confidence interval and statistical significance: A practical guide for biologists. Biological Reviews, 82, 591-605.

Päivinen, J., Ahlroth, P., Kaitala, V., Kotiaho, J. S., Suhonen, J., \& Virola, T. (2003). Species richness and regional distribution of myrmecophilous beetles. Oecologia, 134, 587-595.
Päivinen, J., Ahlroth, P., Kaitala, V., \& Suhonen, J. (2004). Species richness, abundance and distribution of myrmecophilous beetles in nests of Formica aquilonia ants. Annales Zoologici Fennici, $41,447-454$.

Parmentier, T. (2010). Taakverdeling en voedselecologie bij de werksters van Formica rufa en Formica polyctena (Master thesis). Ugent, Ghent, Belgium: Terrestrial Ecology Unit.

Parmentier, T., Dekoninck, W., \& Wenseleers, T. (2014). A highly diverse microcosm in a hostile world: A review on the associates of red wood ants (Formica rufa group). Insectes Sociaux, 61, 229-237. http://dx.doi.org/10.1007/s00040-014-0357-3

Peres-Neto, P. R., Legendre, P., Dray, S., \& Borcard, D. (2006). Variation partitioning of species data matrices: Estimation and comparison of fractions. Ecology, 87, 2614-2625. http://dx.doi.org/10.1890/0012-9658

Ranius, T. (2000). Minimum viable metapopulation size of a beetle, Osmoderma eremita, living in tree hollows. Animal Conservation, 3, 37-43. http://dx.doi.org/10.1111/j.1469-1795. 2000.tb00085.x

Roberts, M. (2001). Spiders of Britain and Northern Europe. Collins Field Guide.

Robinson, N. A., \& Robinson, E. J. H. (2013). Myrmecophiles and other invertebrate nest associates of the red wood ant Formica rufa (Hymenoptera: Formicidae) in north-west England. British Journal of Entomology and Natural History, 26, 67-88.

Rosengren, R., Fortelius, W., Lindström, K., \& Luther, A. (1987). Phenology and causation of nest heating and thermoregulation in red wood ants of the Formica-rufa group studied in coniferous forest habitats in southern Finland. Annales Zoologici Fennici, 24, 147-155.

Seifert, B. (2007). Die Ameisen Mittel- und Nordeuropas. Görlitz: Lutra Verlags- und Vertriebsgesellschaft.

Seifert, B., Kulmuni, J., \& Pamilo, P. (2010). Independent hybrid populations of Formica polyctena X rufa wood ants (Hymenoptera: Formicidae) abound under conditions of forest fragmentation. Evolutionary Ecology, 1219-1237. http://dx. doi.org/10.1007/s10682-010-9371-8

Skinner, G. (1980). The feeding habits of the wood-ant, Formica rufa (Hymenoptera: Formicidae), in limestone woodland in north-west England. Journal of Animal Ecology, 49, 417-433. http://dx.doi.org/10.2307/4255

Thomas, J. A., Bourn, N. A. D., Clarke, R. T., Stewart, K. E., Simcox, D. J., Pearman, G. S., et al. (2001). The quality and isolation of habitat patches both determine where butterflies persist in fragmented landscapes. Proceedings of the Royal Society of London Series B - Biological Sciences, 268, 1791-1796.

Tsiafouli, M. A., Kallimanis, A. S., Katana, E., Stamou, G. P., \& Sgardelis, S. P. (2005). Responses of soil microarthropods to experimental short-term manipulations of soil moisture. Applied Soil Ecology, 29, 17-26. http://dx.doi.org/10.1016/ j.apsoil.2004.10.002

van Straalen, N. M., \& Verhoef, H. A. (1997). The development of a bioindicator system for soil acidity based on arthropod pH preferences. Journal of Applied Ecology, 34, 217-232. http://dx.doi.org/10.2307/2404860

Available online at www.sciencedirect.com

\section{ScienceDirect}




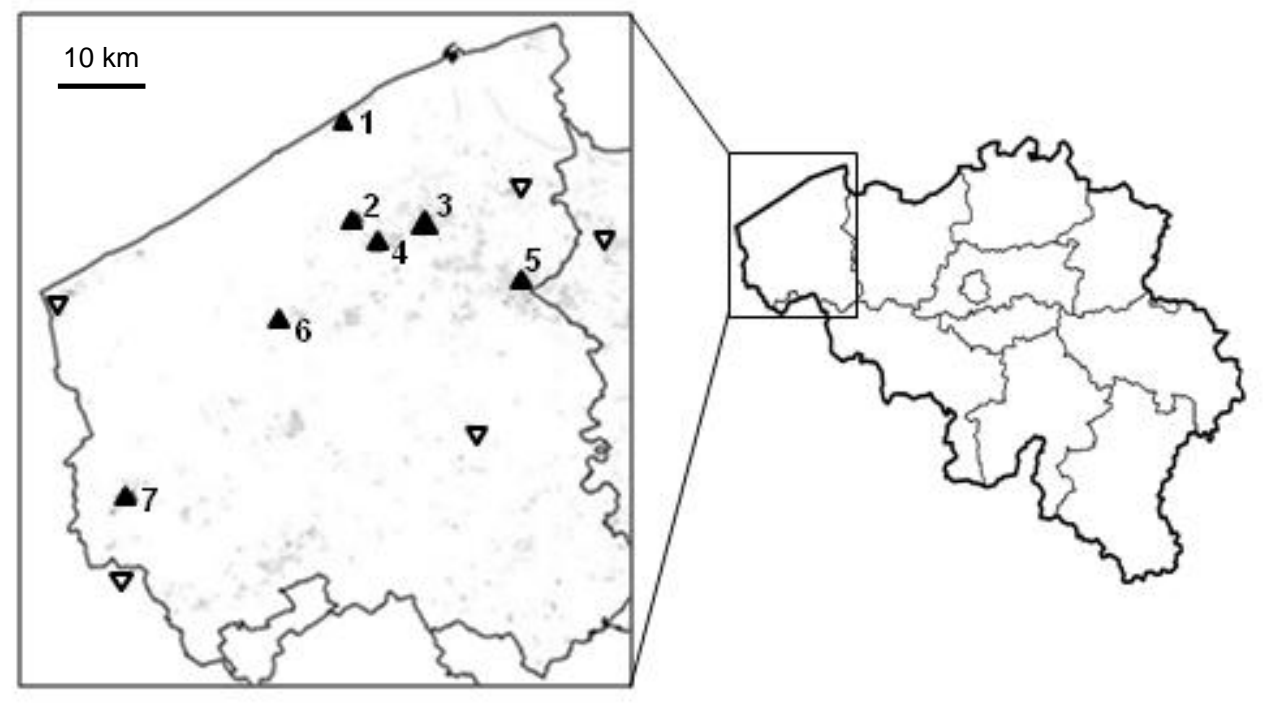




\section{DE HAAN}

\section{$\boldsymbol{\Delta}$ sampled mound}

$\boldsymbol{\nabla}$ unsampled mound

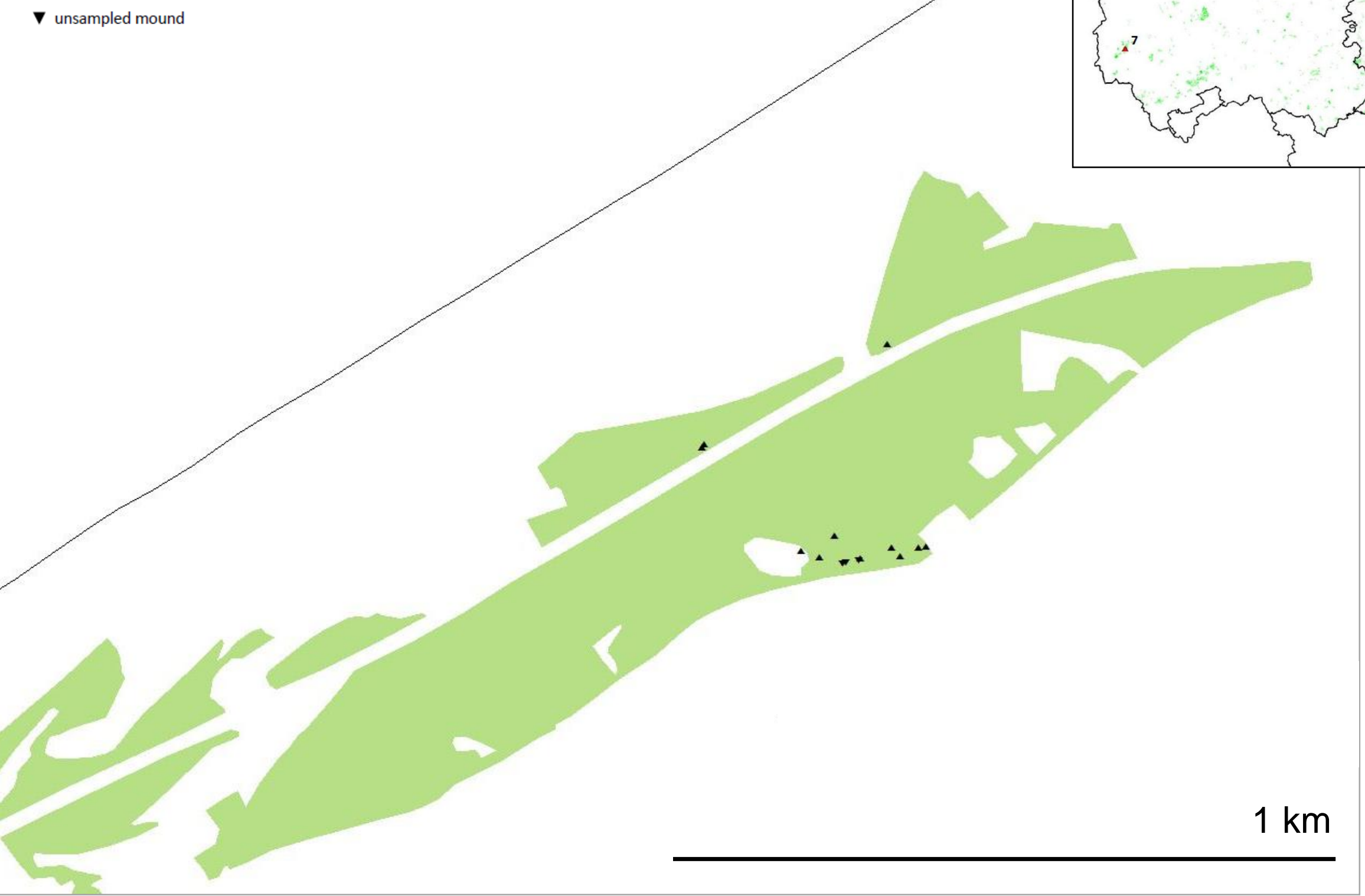




\section{BEISBROEK}

A sampled mound

$\boldsymbol{\nabla}$ unsampled mound

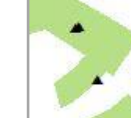

4

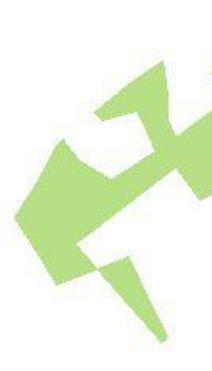

(

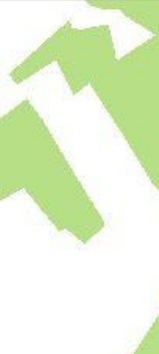

.

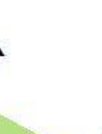

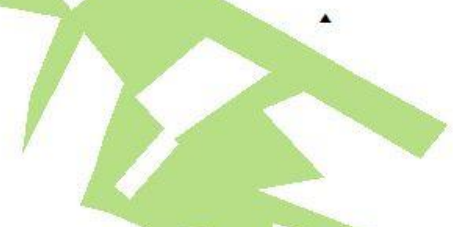

.

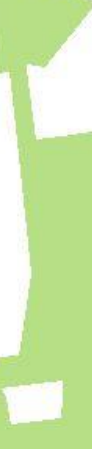




\section{AARTRIJKE}

sampled mound

$\boldsymbol{\nabla}$ unsampled mound
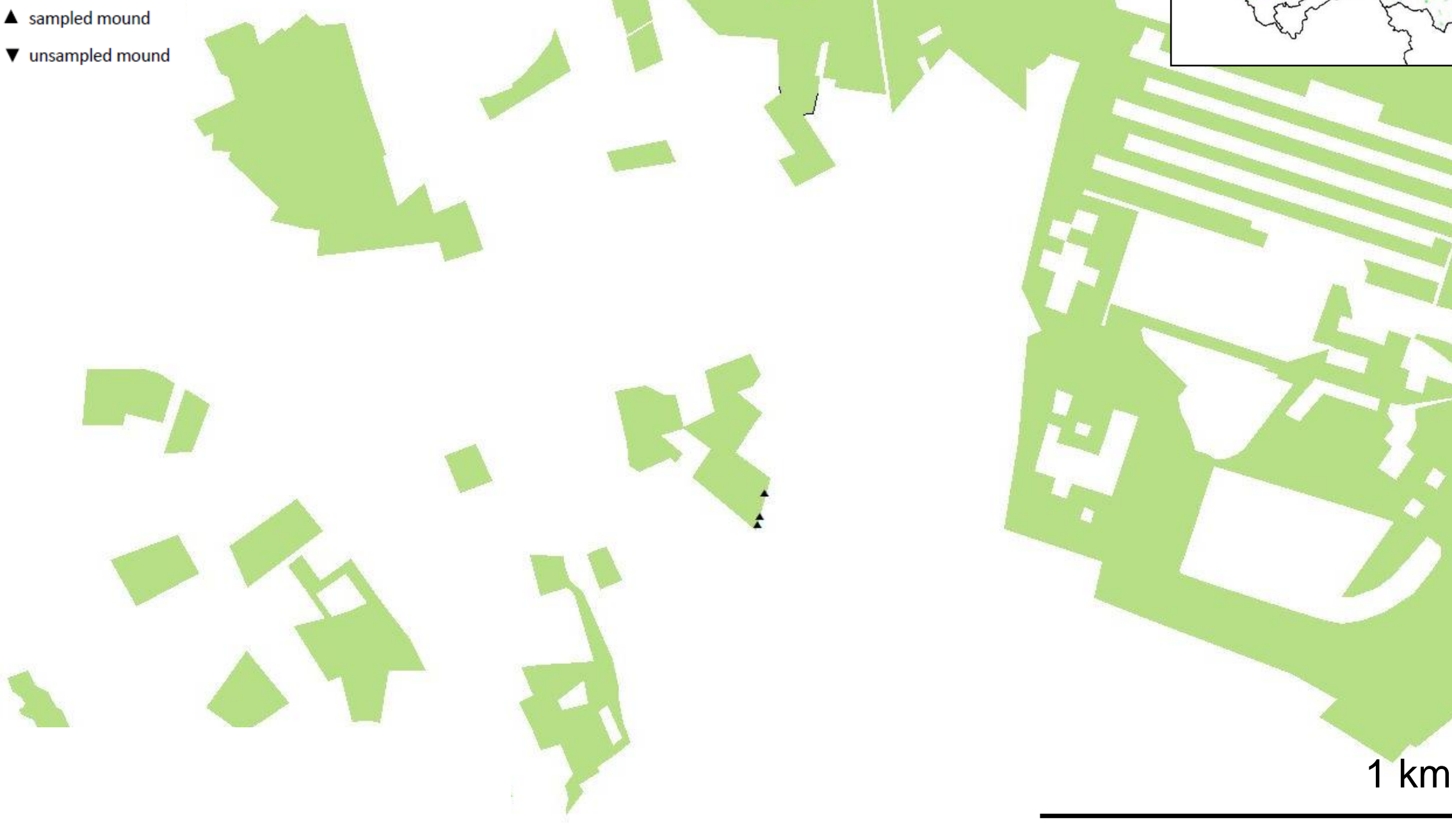


\section{BEERNEM}

A sampled mound

$\boldsymbol{\nabla}$ unsampled mound 


\section{VLADSLO}

$\boldsymbol{\Delta}$ sampled mound

$\boldsymbol{\nabla}$ unsampled mound

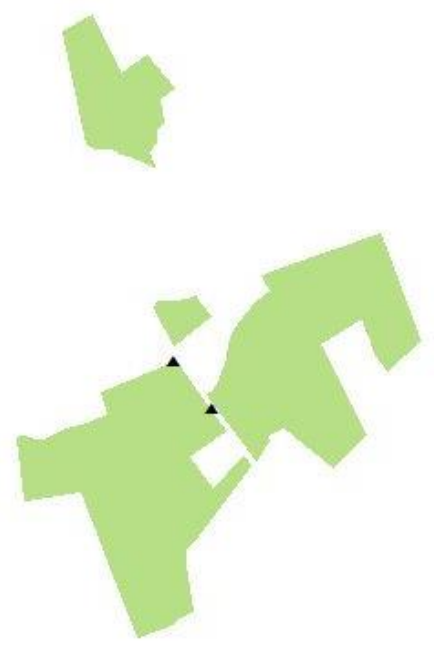




\section{WEST-VLETEREN}

A sampled mound

$\boldsymbol{\nabla}$ unsampled mound 